\title{
Stem cell grafts as therapeutic tools for central nervous system disorders
}

\author{
Alcyr A. de Oliveira, Alexsandro Haeser and Patrícia Pranke \\ Universidade Federal do Rio Grande do Sul, Brazil
}

\begin{abstract}
The last few years have seen a growing interest in stem cell research. The media has helped to keep attention to the subject making it as popular as therapeutic cloning. A number of studies highlighted the importance of stem cells as prospective therapy for neurodegenerative conditions. The possibility of successful treatment for such pathologies using stem cells has raised enormous hope. Whilst in some countries biotechnologists have realised the commercial potential of the field, human stem cell research and its clinical applications have constantly been subject of ethical and legal debate. The present review brings an overview of recent aspects of stem cell research for central nervous system disorders, with special attention to Parkinson's and Alzheimer's diseases, cerebral ischemic insult and spinal cord injury. Furthermore, the ethical implications regarding the use of embryonic stem cells as a fundamentally more promising cell type are discussed. Keywords: stem cells, Parkinson's disease, Alzheimer's disease, stroke, spinal cord injury.
\end{abstract}

Received 22 December 2006; received in revised form 12 March 2008; accepted 14 March 2008. Available online 20 May 2008

\section{Introduction}

A scientific revolution has recently begun involving pre-clinical and clinical trials targeting diseases of the central nervous system (CNS). To a great extent, this is due to evidence that the adult brain contains cells capable of producing new neurones, as well as reports showing that implanted stem cells may substitute lost or malfunctioning cells in the CNS. Thus, untreatable pathologies, such as spinal cord injury, cerebral ischemia, and Parkinson's and Alzheimer's diseases, may become candidates for more permanent treatments than those offered by conventional pharmacological approaches.

Stem cells (SC's) are a very special type of cell with a great capacity for differentiation, migration and mitosis. There are, basically, two types of SC's: embryonic and adult. Embryonic SC's are found in the initial period of embryonic development, shortly after fertilization of the egg and have the capacity to differentiate into any tissue of the body (Zeng, 2006; Menendez, 2006). Adult SC's present some characteristics of immature cells, such as

Alcyr Alves de Oliveira, Instituto de Psicologia, Universidade Federal do Rio Grande do Sul, Brazil. Alexsandro Haeser, Faculdade de Farmácia, Universidade Federal do Rio Grande do Sul, Brazil. Patrícia Pranke, Faculdade de Farmácia e PPG em Medicina, Universidade Federal do Rio Grande do Sul, Brazil. Correspondence regarding this article should be sent to Dr. Alcyr Oliveira, Universidade Federal de Ciências da Saúde de Porto Alegre, Depto. de Saúde Coletiva, Rua Sarmento Leite, 245 - Porto Alegre-Brazil, CEP 90.050-170. Phone: +55-51-3303-9000; Fax: +55-51-3303-8810. Email: alcyr.oliveirajr@gmail.com a high capacity for cellular division and differentiation (Huh, Pan, Mysorekar, \& Mills, 2006; Reubinoff et al., 2001; Rogers \& Casper, 2004; Roisen et al., 2001; Stein, Rozen, Kaufman, \& Lerner, 2006; Stein, Zhu, \& Emerson, 2004; Tarnowski \& Sieron, 2006; Wang et al., 2004).

In recent years, our knowledge of the functional and morphological aspects of these cells and their culture conditions has increased considerably. This has made it possible to isolate and proliferate these cells in vitro (Thomson \& Odorico, 2000), as well as to genetically modify them (Gokhan, Song, \& Mehler, 1998; Himes et al., 2001; Nakafuku \& Nakamura, 1995; Redies, Lendahl, \& McKay, 1991). Several laboratories have investigated the implantation of these cells in animal models of neurodegenerative diseases and their responses to growth factors. Also, the increasing knowledge of the physiopathology of many neurodegenerative conditions, such as Alzheimer's disease, has prompted new treatment possibilities using stem cells (Oliveira \& Hodges, 2005).

\section{Stem cells: concepts and properties}

Embryonic SC's are present in the first stage of development until the blastocyst phase, and are capable of self-renewal, generating identical copies. After the blastocyst phase, three cellular germ layers called ectoderm, mesoderm and endoderm, originated in the gastrula phase, will differentiate and give rise to all body tissues (Odorico, Kaufman, \& Thomson, 2001). The cells that constitute the CNS share a common origin with those forming the skin, eyes, and pituitary gland: the ectoderm. 
Self-renewal and differentiation are associated with the capacity to migrate to the parenchyma, observed in embryonic SC's after implantation. These properties enable the use of SC's in cell replacement therapy (Abranches, Bekman, Henrique, \& Cabral, 2003). However, several issues have yet to be understood before clinical trials can start. Standardised immunosuppressive protocols are required in order to prevent cell rejection in allogenic transplants. There are also concerns regarding the condition of the implanted cells and what line of differentiation they may adopt. Another concern is the currently limited knowledge of cell culture heterogeneity and growth factors (Schuldiner, Yanuka, Itskovitz-Eldor, Melton, \& Benvenisty, 2000). In vitro studies have shown a high rate of differentiation variability of primate embryonic stem cells (Pau \& Wolf, 2004). Also, the adequacy of animal models of some CNS pathologies often prohibits adequate pre-clinical scrutiny, increasing the risks of translating experimental studies for human clinical trials (McCabe et al., 2000).

\section{The central nervous system and its stem cells}

Along-held belief stated that the production of new neuronal cells in the CNS could only occur during the embryonic development, and not in the adult brain (Gage, 1998; Gage, 2000). This assumption by Ramón y Cajal (apud Gage, 1998) was only recently brought into question after evidence of selfrenewing and multipotent adult brain stem cells (Gage, 1998; Gage, 2000). Since these cells are not capable of halting the degeneration of the brain, such evidence failed to inspire hope for their therapeutic application. On the other hand, the brain's capacity to maintain self-renewing cells supports the idea that implanted cells have a nourishing environment in which to develop.

The brain and the spinal cord, which together comprise the $\mathrm{CNS}$, are delicate and complex structures susceptible to various types of insults. From the early development to the aging adult, neuronal death may cause devastating brain damage with eventual impact on all aspects of human functioning. Since the brain controls all higher mental and cognitive functions, a lack of recovery in the CNS challenges health care professionals. Therefore, the alleviation of such damage is a major therapeutic objective.

The most important role of neural networks in the brain is to transmit signals and allow communication between cells and, ultimately, structures involved in functions, such as memory or motor activity. For instance, death or dysfunction of dopaminergic neurones in the nigrostriatal pathway is the core pathology in Parkinson's disease. Consequently, the main direction of current therapy is the pharmacological approach.

\section{Neural stem cells}

During the foetal stage, SC's of the neural lineage are developing abundantly and although they can be found in the adult brain, it is not an easy task. Some reports have indicated the presence of stem cells in brain areas such as the hippocampus, subventricular zone (SVZ) and olfactory bulb (Alvarez-Buylla, Seri, \& Doetsch, 2002; Gage, 2002; Gage,
Ray, \& Fisher, 1995; Galvin \& Jones, 2002; Song, Stevens, $\&$ Gage, 2002). These cells are called neural stem cells and are non-differentiated cells with high proliferation and selfrenewing capacity that will give origin to all $\mathrm{CNS}$ cells including neurones (Gage, 2000). In all stages of development, neural stem cells lie on the basal layer of the SVZ. In this niche, stem cells divide and give rise to progenitor cells committed to the neural lineage. It is from the SVZ that they will migrate to different areas of the developing brain (Gage, 1998; Gage, 2002; Garcia-Verdugo et al., 2002). During differentiation, neural SC's acquire markers that respond to the developing CNS environment and determine their consequent lineage (Gage, 1998; Gage, 2002; Garcia-Verdugo et al., 2002).

The differentiation capacity of neural SC's has been debated. The multipotential capacity of these cells has been shown in several studies (Oliveira, Grygorian, \& Hodges, 2000a; Sinden et al., 1997; Vescovi et al., 1999; Vescovi \& Snyder, 1999). It has also been demonstrated that neural SC's are able to differentiate into non-neural cell lineages, such as blood (Bjornson, Rietze, Reynolds, Magli, \& Vescovi, 1999), and the reverse is also possible, as epithelial cells in the appropriate condition may differentiate into neuronal cells (Joannides et al., 2004). Although the capacity of embryonic SC's is recognized as promising for future therapeutics, SC's from other origins, such as bone marrow, can also be of great value.

\section{Other sources of non-embryonic stem cells}

Due to practical and ethical implications in obtaining cells from embryos, the research in this field is being restricted. In several countries, research on embryonic material is limited to a very few available cell lines. Other countries have restrictive laws for the use of embryonic material. Ethical issues are also constantly raised on the basis of religious or philosophical arguments regarding the use of human tissue for research. Although research on embryonic stem cells is considered very important for medical purposes, the possibility of finding cells with a similar potential in adult organisms has opened a variety of possible sources for stem cells.

In any case, research on embryonic, foetal or adult stem cells is being carried out in several laboratories and may determine the future of cell transplantation. Embryonic stem cells are generally cells that have been harvested from embryos up to the $10^{\text {th }}$ day after fertilization. These cells are usually considered to be the most flexible and capable of differentiation: totipotent. After this initial time, before birth, the material obtained for research or transplantation is regarded as foetal tissue. Although it is possible to obtain cells from the umbilical cord, all SC's obtained from birth to adulthood are called adult stem cells.

\section{Umbilical cord blood}

Cells collected from the umbilical cordblood are a promising source of cells for grafting. Some reports have shown that the umbilical cord blood contains cells that may express neuronal markers (Buzanska, Machaj, Zablocka, Pojda, \& DomanskaJanik, 2002; Sanchez-Ramos et al., 2001). The umbilical cord is also a rich source of hematopoietic and mesenchymal 
stem cells (Wang et al., 2004) and has compelling potential for therapeutic use in neurological diseases due to the ability of these cells to differentiate into neural lineages (Buzanska et al., 2002; Jeong et al., 2004; Li et al., 2004; McGuckin, Forraz, Allouard, \& Pettengell, 2004; Rogers \& Casper, 2004; Sanchez-Ramos et al., 2001).

\section{Bone marrow stem cells}

Much of the research into adult SC's is carried out with bone marrow cells. It has been shown that these cells have the potential to proliferate and differentiate into several types of cells. Bone marrow stem cells (BMSC) have two major advantages over other cell sources: accessibility and immunological advantages. The use of BMSC's for grafts circumvents the ethical concerns attached to the use of embryonic cells. It also brings technical and practical solutions, such as simpler cell collection, since it has been practiced for some time already in bone marrow transplants. The cells could also be obtained from the recipient, unless the treatment is for a genetic disease (Filip, Mokry, Karbanova, Vavrova, \& English, 2004; Hermann et al., 2004; Jori et al., 2004; Tondreau et al., 2004).

\section{Stem cells and neural transplantation}

Over a hundred years ago, the first attempts at grafting CNS tissue in the adult brain were reflected in the pioneering studies of Walter G. Thompson in 1890, where cats and dogs were used to investigate the survival of grafted tissue. Thompson wrote: "Of course, I had no expectation of being able to restore abolished function by the operation, but the question of vitality of the brain tissue and the course of its degeneration is a subject which is of very wide interest." It has, indeed, shown a proof of principle.

Nevertheless, it was only in the last 30 years that the technology required for successful transplantation of CNS tissue has been developed. In 1976, a work published by Lund and Hauschka showed that superior collicular fragments transplanted from foetal to newborn rat brains developed a complex internal organization and received visual afferents from the host brain (Lund \& Hauschka, 1976). This study highlighted the possibility that intracerebral CNS-derived transplants may be able to integrate with damaged neural tissue.

Other studies from the same decade showed successful transplantation of immature central and peripheral neurons into the CNS (Stenevi, Bjorklund, \& Svendgaard, 1976). At that early stage, success in neural transplantation was limited to transplant survival. However, it was becoming clear that implants of neural tissue into damaged CNS could ameliorate symptoms of motor and cognitive dysfunction.

When the donor tissue is immature, from foetal or neonatal sources, and the site of implantation is richly vascularised, the chances of transplant survival are hugely increased (Barker \& Dunnet, 1999). Promising results from SC research have shown that stem cell grafts can successfully recover animal models of Parkinson's disease (Bjorklund et al., 2002), Alzheimer's disease (Oliveira \& Hodges, 2005), ischemic insult (Sinden et al., 1997), spinal cord injury (Park et al., 1999) and other CNS injuries. Therefore, the understanding of the brain's capacity and plasticity has changed from Cajal's non-regenerating view to an exciting perspective of therapeutic regeneration. The era of stem cells has begun.

\section{Prospective cell therapy for Parkinson's disease}

Parkinson's disease (PD) is a progressive neurodegenerative disorder, which affects movement control, including speech and 'body language'. Although the incidence is higher in the elderly population, more than one in ten sufferers are diagnosed before the age of 50 (Morens et al., 1996). This chronic incurable disease occurs due to a malfunction of dopaminergic cells in the striatal pathway or cell death in the substantia nigra. The regions innervated by these dopaminergic projections have connections to cortical areas responsible for fine movement control (Isacson, 2002).

The World Health Organization has estimated an increase in the number of PD patients, as the general population grows older (Baker \& Gershanik, 2006). Because of this growth, it is imperative to promote the assessment of health needs and reinforce research into new therapeutic processes. Stem cell research for the treatment of Parkinson's disease represents the most promising alternative.

Neural transplantation in animal models or patients with Parkinson's disease is based on the perspective that there is no cure and the current treatment is centred on the pharmacological relief of symptoms and its secondary consequences (Wheatley et al., 2002). The stem cell implantation method may permit the re-establishment of the dopaminergic connections in the striatal pathway. Preclinical studies have shown that embryonic stem cells are capable of surviving and producing dopamine in the host tissue (Bjorklund et al., 2002; Hagell \& Brundin, 2001; Lindvall, 2002). It is well established that embryonic mesencephalic tissue transplants survive in human Parkinsonian brains. The successful results in clinical trials show that cell replacement therapy is viable (Lindvall \& Hagell, 2002).

However, a number of questions remain to be answered. One of these is whether implants are able to promote full recovery of very specific affected brain areas. Some reports of bilateral implanted tissue into the putamen showed that 30 to $40 \%$ of patients presented symptom reduction and higher levels of the marker f-dopa in the putamen, suggesting graft survival (Hagell \& Brundin, 2001; Lindvall \& Hagell, 2002). Despite these findings, the level of recovery measured was only $50 \%$ (Hagell \& Brundin, 2001; Lindvall \& Hagell, 2002). Other important issues need to be addressed, such as the mechanisms controlling cell differentiation, survival and migration after grafting as well as in vitro, sites of implantation and amount of cells to be grafted.

Most scientists working with Parkinson's disease only consider the engraftment to be successful if the implanted cells present the dopamine releasing machinery and morphological and physiological characteristics of adult neurones (Galvin \& Jones, 2002; Hagell \& Brundin, 2001; Lindvall \& Hagell, 2002). In adequate laboratory conditions, SC's can be differentiated and fully screened for their dopaminergic function, defects or contamination, and then implanted. 
The current neural transplantation research in PD patients has been carried out using foetal material obtained from donors whose pregnancy was interrupted (Freed et al., 2001; Lindvall, 1995; Lindvall et al., 1989). Although there are few reports of stem cell grafting in PD patients (Levesque, 2004), it seems that this is the most promising treatment and the successful implantation of foetal tissue has shown proof of principle. Parkinson's disease consumes billions of dollars worldwide every year and has a profound impact on the patient's quality of life. Preclinical and clinical studies have shown that neural transplantation of stem cells for Parkinson's offers a promising perspective. It is the most advanced cell replacement therapy for the CNS so far. Although some concern still remains, the promise of successful stem cell replacement therapy gives grounds for hope.

\section{Prospective cell therapy for Alzheimer's disease}

Alzheimer's disease $(\mathrm{AD})$ is a neurodegenerative pathology characterized by neuronal degeneration. $\mathrm{AD}$ has unknown causes that lead to gradual death of the cells located in the nucleus basalis of Meynert and its pathway to the neo-cortex (Butcher \& Woolf, 1986; Whitehouse et al., 1982; Whitehouse et al., 1983). Although all neurotransmitter systems are affected in $\mathrm{AD}$, the cholinergic system is recognized as the first to be damaged and lose cells (Butcher \& Woolf, 1986; Davies \& Maloney, 1976; Perry et al., 1978). Other neuropathological events are hallmarks of the disease, such as beta amyloid deposition and formation of intracellular neurofibrillary tangles, that can only be shown in post-mortem histological analysis (Vickers et al., 2000).

AD'smainsymptomisprogressivememorydegeneration (Katzman, 1989). The World Health Organization estimates that there are currently about 18 million people worldwide suffering from AD. Projections suggest that this number will nearly double to 34 million by 2025 ; much of this increase will take place in the developing countries due to population aging as a result of improvement in health conditions (Gauthier, Burns, \& Pettit, 1997).

Cholinergic circuitry reconstruction represents the main objective for cell therapy in Alzheimer's disease (Oliveira \& Hodges, 2005). Animal models using induced lesion of the cholinergic projection system show analogue disruptions of behavioural and cognitive performance similar to those observed in patients, such as memory loss, attention deficit, anxiety, mood instability and learning difficulty (Cummings, 2000; Davis et al., 1999; Muir, Page, Sirinathsinghji, Robbins, \& Everitt, 1993). In such models, the implantation of stem cells has shown promising results, with amelioration of memory loss (Grigoryan, Gray, Rashid, Chadwick, \& Hodges, 2000; Sugaya, 2005; Wang et al., 2006).

As Alzheimer's disease usually affects elderly people and a stem cell engraftment procedure would probably involve surgical intracranial intervention, all cases must be very well assessed. Stem cell implantation has to be anticipated, well planned and tested. A number of research groups around the world are testing hypotheses that may bring beneficial results for patients. In a preclinical study, Oliveira and colleagues (2000) showed that rats with lesions to the basal forebrain had their memory and learning performance ameliorated after receiving grafts of either immortalized murine stem cell lines or human stem cells into the cholinergic projection (Grigoryan et al., 2000; Oliveira, Grygorian, \& Hodges, 2000b; Oliveira et al., 2002). Results showing improved performance in cognitive tasks suggest that Alzheimer's disease may be a target for future treatment with stem cells (Grigoryan et al., 2000; Sugaya, 2005; Sugaya \& Brannen, 2001; Wang et al., 2006). However, in order to achieve these aims, several important steps need to be taken, and research will certainly play a major role in this development (Blesch \& Tuszynski, 2004; Fernandez et al., 2004). Greater understanding of the neurobiological and molecular factors that determine the progress of the disease will probably be the key to the development of safe treatments for patients.

\section{Prospective cell therapy for stroke}

Genetic, dietary and life style elements, such as smoking, represent risk factors for cerebral vascular accidents (CVAs), which affect patients in all age ranges, education or family background. The most common cerebral ischemic insults result from vascular disturbance, blood supply interruption and consequent cell death due to metabolic and nutritive deficiency. Stem cell therapy may be used in an attempt at revascularization and circuitry reconstruction.

Some preclinical studies have demonstrated that neural stem cells grafted directly to the brain migrate to the injured areas (Hodges et al., 2000; Modo, Cash et al., 2002). These and other studies showed significant improvement in several behavioural tests suggesting functional recovery (Modo, Cash et al., 2002; Modo, Rezaie et al., 2002; Sinden et al., 1997; Veizovic, Beech, Stroemer, Watson, \& Hodges, 2001). The influence of grafted stem cells on the action of particular proteins that may be involved in the regeneration process has also been investigated. For example, Modo observed that the apolipoprotein E or ApoE, which is a protein involved in neuro-protection, increased in several regions of the brain after neural stem cell grafting. These authors also demonstrated that ApoE was expressed in host astrocytes and grafted cells (Modo, Hopkins, Virley, \& Hodges, 2003).

Recently, a research group reported a successful bone marrow stem cell based treatment on an ischemic patient (Freitas, André, \& Mendez-Otero, 2005; Mendonça et al., 2006). The cells used in this procedure were intravenously infused and although the procedure might not be considered an implantation, the results were reported as promising.

To better understand the effects of stem cell grafts in this sort of injury, continuous scientific investigation into the neurochemical and molecular mechanisms involved in the relationship between grafted cells and host tissue is necessary. To improve our knowledge, it is crucial to understand which trophic and growth factors regulate cell interaction, differentiation and migration mechanisms. 


\section{Prospective cell therapy for spinal cord injury}

Spinal cord injuries render the victim partially or completely physically disabled. The incidence may vary from country to country, however, falling accidents are the most common cause followed by car accidents, stabbings or shootings, and sports backbone accidents (Kennedy, Rogers, Speer, \& Frankel, 1999; Oller et al., 1992; Scher, 1998; Turgut, Akpinar, Akalan, \& Ozcan, 1996; Vogel \& Anderson, 2003). The variety of insults that can cause spinal injury may also lead to different types of damage and disability. For many, spinal cord injury is the greatest challenge for any kind of treatment aimed at central nervous system repair. Successful treatment is not simple and implies a reconstruction of long axonal connections and regeneration of communication in the nervous system.

The degeneration of transected axons leads to the necrotic deterioration of distal axons following disconnection from the cell body. Furthermore, a spinal insult is typically associated with inflammatory responses and the formation of astrocytic scar tissue, which provides a barrier to regenerative regrowth. This, associated with changes in the capacity of such glial scars to secrete and remove toxic molecules from their environment, further impedes the regenerative process. Other important events take place, such as the formation of the so-called "syrinx", which are cysts filled with cerebrospinal fluid that expand in both rostral and caudal directions resulting in further development of symptoms progressively affecting more levels of the cord (Brodbelt \& Stoodley, 2003).

For spinal cord insults, the most studied repair strategy involving stem cells is the implantation of cells directly into the affected area, which is aimed at promoting the rebuilding of functional circuitry by bridging over the glial scar (Cizkova, Rosocha, Vanicky, Jergova, \& Cizek, 2006; Hendricks et al., 2006; Ishii et al., 2006; Nishio et al., 2006; Urdzikova et al., 2006). Both stem cell and tissue implantation therapy programs target the re-myelination of existing neurones, helping them to return to their functional status (Cizkova et al., 2006; Hendricks et al., 2006; Ishii et al., 2006; Nishio et al., 2006; Okano et al., 2003; Rezvani et al., 2001; Urdzikova et al., 2006). Another possibility is to graft the stem cells before glial scarring takes place, and thus maximize the differentiation of the cells into neurones and myelinating oligodendrocytes.

Grafting before the glial scar is completely formed is another possibility that takes advantage of trophic and inflammatory signals and may direct neuronal and oligodendrocytic differentiation. Some studies have reported these signals acting when the implantation occurred nine days after lesion, but not when the implants happened immediately after the lesion (Ogawa et al., 2002). It is very important that survival and differentiation of the implanted cells are guaranteed. It is fundamental that the implanted cells have a stimulating environment to promote the needed differentiation and cell communication from the host's healthy cells to grafted cells. Pre-clinical studies have shown differentiated neural stem cells implanted after injury producing axonal regrowth, establishing cell connection and promoting functional benefit (Iwanami et al., 2005; McDonald et al., 1999; Nishio et al., 2006; Ogawa et al., 2002). Also, initial clinical trials have been reported presenting promising results (Kang et al., 2005). Such results may reinforce great hope among patients suffering from serious disabling conditions. However, as in any experimental preclinical study, there are still several aspects that need further investigation.

\section{Conclusions}

Stem cell therapy is a research field with promising prospects for the treatment of central nervous system conditions. These cells have the potential to develop into many types and subtypes of cells and are capable of in vitro long-term survival and self-renewal. These properties enhance their therapeutic capacity and availability for transplantation. Although the presence of stem cells in the adult brain has been well documented (Cameron \& McKay, 1998; Gage, 2002; Gage, Kempermann, Palmer, Peterson, \& Ray, 1998; Lim, Flames, Collado, \& Herrera, 2002; Ray, Palmer, Suhonen, Takahashi, \& Gage, 1997), due to developmental restrictions, neuronal cells are rarely renewed and most probably not in restorative quantities. Therefore, stem cell engraftment therapy may stand out as an alternative for cell replacement in CNS injuries and diseases.

The use of embryonic or adult (post-natal) stem cells for grafting is currently in open debate all over the world. The discussion about the therapeutic use of stem cells and its sources has been held on ethical and scientific perspectives and will certainly determine the future of research and therapy. Resolving certain technical issues such as in vitro and in vivo cell control, accessibility and availability either of embryonic, foetal or adult cells will help to have a definitive choice of source and methods for clinical uses.

The way to solve at least part of these problems is currently being tested in different laboratories. Some studies show successful cell control by genetic modification through the introduction of oncogenes capable to control cell division under certain conditions (Jat et al., 1991; Nakafuku \& Nakamura, 1995; Noble et al., 1993; Noble, Groves, Ataliotis, Ikram, \& Jat, 1995). Regarding the problems with stem cell sources, it seems that the methods for adult stem cell collection are already used in the clinical practice and, therefore, pose less ethical concerns. Methods similar to those used in bone marrow transplantation or umbilical cord blood collection can be used to obtain adult stem cells. However, there is a general claim that embryonic stem cells have a greater potential because of their totipotency. Although the potentiality of stem cells from different sources is still a topic for debate among scientists, there is little doubt that further research is needed to better understand the potential of different cell types for transplants.

Several experiments have demonstrated that grafts of stem cells are capable to ameliorate a variety of CNS conditions. However, certain crucial issues, such as functional connectivity, in vivo differentiation and survival, potential for migration to areas of lesion, 
host immunoreactions or mechanisms regulating these functions, are still to be addressed. In the laboratory, SC's can be differentiated into specific cell types lacking neurological conditions and then implanted. In spite of that, one of the most attractive characteristics of SC's is their ability to react to the host tissue and interact with other cells after implantation (Sinden et al., 1997). Cell replacement is dependent on several factors. Migration and differentiation capacity, as well as cell interaction and integration with the host, are a matter of investigation and cannot completely explain functional recovery in preclinical studies. Although it seems crucial that differentiated cell derivatives must function in a physiologically normal way, this is not the most important issue. Scientists have to resist the pressure to establish SC's therapy as definitive and ready solution. In the current stage, a setback can easily produce serious delays in research funding, as seen with foetal tissue transplants for Parkinson's disease (Check, 2003; Olanow et al., 2003).

Also, the costs of clinical trials are high and there are several other important issues that need to be carefully considered. Although preclinical studies furnish information on important basic mechanisms involved in stem cell grafting, there are some technical points that can only be resolved with clinical trials. It is possible that many patients may volunteer for such a promising restorative therapy; however, their health condition is often poor and getting worse. It is important to make it clear that stem cell research is still an experimental procedure and serious preclinical and clinical trials have to be carried out. Although only a few successful clinical studies have been performed, it does not seem to be overenthusiastic to say that many currently untreatable neurological conditions will soon be treatable using these techniques.

\section{Acknowledgment}

Dr. AA Oliveira was supported by a ProDoc fellowship from CAPES/Brazil No. 00132/03-9.

\section{References}

Abranches, E., Bekman, E., Henrique, D., \& Cabral, J. M. (2003). Expansion and neural differentiation of embryonic stem cells in adherent and suspension cultures. Biotechnology Letters, 25(9), 725-730.

Alvarez-Buylla, A., Seri, B., \& Doetsch, F. (2002). Identification of neural stem cells in the adult vertebrate brain. Brain Research Bulletin, 57(6), 751-758.

Baker, M., \& Gershanik, O. (2006). Neurological disorders: a public health approach - Parkinson. In World Health Organization (Ed.), Neurological disorders: public health challenges. Geneva: WHO Press.

Barker, R. A., \& Dunnet, S. B. (1999). Neural repair, transplantation and rehabilitation. Hove: Psychology Press Ltd.

Bjorklund, L. M., Sanchez-Pernaute, R., Chung, S., Andersson, T., Chen, I. Y. C., McNaught, K. S. P., Brownell, A. L., Jenkins, B., Wahlestedt, C., Isacson, O. (2002). Embryonic stem cells develop into functional dopaminergic neurons after transplantation in a Parkinson rat model. Proceedings of the National Academy of Sciences of the USA, 99(4), 2344-2349.

Bjornson, C. R. R., Rietze, R. L., Reynolds, B. A., Magli, M. C., \& Vescovi, A. L. (1999). Turning Brain into Blood: A Hematopoietic Fate Adopted by Adult Neural Stem Cells in Vivo. Science, 283(5401), 534-537.

Blesch, A., \& Tuszynski, M. H. (2004). Gene therapy and cell transplantation for Alzheimer's disease and spinal cord injury. Yonsei Medical Journal, 45, 28-31.
Brodbelt, A. R., \& Stoodley, M. A. (2003). Post-traumatic syringomyelia: a review. Journal of Clinical Neuroscience, 10(4), 401-408.

Butcher, L. L., \& Woolf, N. J. (1986). Central cholinergic systems: synopsis of anatomy and overview of physiology and pathology. In A. B. Scheibel \& A. F. Wechsler (Eds.), The Biological Substrates Of Alzheimer's Disease (pp. 73-86). New York: Academic Press, Inc.

Buzanska, L., Machaj, E. K., Zablocka, B., Pojda, Z., \& DomanskaJanik, K. (2002). Human cord blood-derived cells attain neuronal and glial features in vitro. Journal of Cell Science, 115(10), 2131-2138.

Cameron, H. A., \& McKay, R. (1998). Stem cells and neurogenesis in the adult brain. Current Opinion in Neurobiology, 8(5), 677680.

Check, E. (2003). Parkinson's transplant therapy faces setback. Nature, 424(6952), 987.

Cizkova, D., Rosocha, J., Vanicky, I., Jergova, S., \& Cizek, M. (2006). Transplants of Human Mesenchymal Stem Cells Improve Functional Recovery After Spinal Cord Injury in the Rat. Cellular and Molecular Neurobiology, 26(7-8), 1167-1180.

Cummings, J. L. (2000). Cognitive and behavioral heterogeneity in Alzheimer's disease: seeking the neurobiological basis. Neurobiology of Aging, 21(6), 845-861.

Davies, P., \& Maloney, A. J. (1976). Selective loss of central cholinergic neurons in Alzheimer's disease. The Lancet, 2,1403 .

Davis, K. L., Mohs, R. C., Marin, D., Purohit, D. P., Perl, D. P., Lantz, M., Austin, G., Haroutunian, V. (1999). Cholinergic markers in elderly patients with early signs of Alzheimer disease. Journal of American Medical Association, 281(15), 1401-1406.

Fernandez, C. I., Alberti, E., Collazo, J., Gonzalez, M. E., Bauza, J. Y., Martinez, L., Rosillo, J. C. (2004). Both, exercise and enriched environment enhance the cognitive improvement related to stem cells grafting to the impaired aged brain: An approach to multifactorial therapy in Alzheimer disease. Neurobiology of Aging, 25, S231-S232.

Filip, S., Mokry, J., Karbanova, J., Vavrova, J., \& English, D. (2004). Local environmental factors determine hematopoietic differentiation of neural stem cells. Stem Cells Development, 13(1), 113-120.

Freed, C. R., Greene, P. E., Breeze, R. E., Tsai, W. Y., DuMouchel, W., Kao, R., Dillon, S., Winfield, H., Culver, S., Trojanowski, J. Q., Eidelberg, D., \& Bahn, S. (2001). Transplantation of embryonicdopamine neurons for severe Parkinson's disease. The New England Journal of Medicine, 344(10), 710-719.

Freitas, G. R., André, C., \& Mendez-Otero, R. (2005). Células-tronco em acidentes vasculares cerebrais: lições de estudos em animais e humanos. Neurociências, 2, (2), 90-95.

Freitas, G. R., Mendonça, M. L. F., Bezerra, D. C., Silva, A. S., Falcão, C. H. E., Gonzales, C., Moreira, R., Haddad, A.F., Tuche, F., Santos, D.P., André, C., Mesquita, C.T., Oliveira, A.A., Elia, V. Dohmnann, H. J., Borojevic, R., Mendez-Otero, R., \& Bohmann, H.F.R. (2006). Safety and feasibility of intra-arterial autologous bone marrow mononuclear cell transplantation in acute ischemic stroke. Stroke, 37, 624-625.

Gage, F. H. (1998). Stem cells of the central nervous system. Current Opinion in Neurobiology, 8(5), 671-676.

Gage, F. H. (2000). Mammalian Neural Stem Cells. Science, 287(5457), 1433-1438.

Gage, F. H. (2002). Neurogenesis in the Adult Brain. Journal of Neuroscience, 22(3), 612-613.

Gage, F. H., Kempermann, G., Palmer, T. D., Peterson, D. A., \& Ray, J. (1998). Multipotent progenitor cells in the adult dentate gyrus. Journal of Neurobiology, 36(2), 249-266.

Gage, F. H., Ray, J., \& Fisher, L. J. (1995). Isolation, characterization, and use of stem cells from the CNS. Annual Reviews in Neuroscience, 18, 159-192.

Galvin, K. A., \& Jones, D. G. (2002). Adult human neural stem cells for cell-replacement therapies in the central nervous system. Medical Journal of Australia, 177(6), 316-318.

Garcia-Verdugo, J. M., Ferron, S., Flames, N., Collado, L., Desfilis, E., \& Font, E. (2002). The proliferative ventricular zone in adult vertebrates: a comparative study using reptiles, birds, and mammals. Brain Research Bulletin, 57(6), 765-775.

Gauthier, S., Burns, A., \& Pettit, W. (1997). Alzheimer disease in primary care. London: Martin Dunitz Ltd.

Gokhan, S., Song, Q., \& Mehler, M. F. (1998). Generation and regulation of developing immortalized neural cell lines. Methods, $16(3), 345-358$.

Grigoryan, G. A., Gray, J. A., Rashid, T., Chadwick, A., \& Hodges, H. (2000). Conditionally immortal neuroepithelial stem cell 
grafts restore spatial learning in rats with lesions at the source of cholinergic forebrain projections cholinergic forebrain projections. Restorative Neurological Neuroscience, 17(4), 1.

Hagell, P., \& Brundin, P. (2001). Cell survival and clinical outcome following intrastriatal transplantation in Parkinson disease. Journal Neuropathology and Experimental Neurology, 60(8), 741-752.

Hendricks, W. A., Pak, E. S., Owensby, J. P., Menta, K. J., Glazova, M., Moretto, J., Hollis, S., Brewer, K. L., \& Murashov, A. K. (2006). Predifferentiated embryonic stem cells prevent chronic pain behaviors and restore sensory function following spinal cord injury in mice. Molecular Medicine, 12(1-3), 34-46.

Hermann, A., Gastl, R., Liebau, S., Popa, M. O., Fiedler, J., Boehm, B. O., Maisel, M., Lerche, H., Schwarz, J., Brenner, R., \& Storch, A. (2004). Efficient generation of neural stem cell-like cells from adult human bone marrow stromal cells. Journal of Cell Science, $117(\mathrm{Pt}$ 19), 4411-4422.

Himes, B. T., Liu, Y., Solowska, J. M., Snyder, E. Y., Fischer, I., \& Tessler, A. (2001). Transplants of cells genetically modified to express neurotrophin-3 rescue axotomized Clarke's nucleus neurons after spinal cord hemisection in adult rats. Journal of Neuroscience Research, 65(6), 549-564.

Hodges, H., Sowinski, P., Virley, D., Nelson, A., Kershaw, T. R., Watson, W. P., Rashid, T., French, S. J., Chadwick, A., Gray, J. A., \& Sinden, J. D. (2000). Functional reconstruction of the hippocampus: fetal versus conditionally immortal neuroepithelial stem cell grafts. Novartis Foundation Symposium, 231, 53-65.

Huh, W. J., Pan, X. O., Mysorekar, I. U., \& Mills, J. C. (2006). Location, allocation, relocation: isolating adult tissue stem cells in three dimensions. Current Opinion in Biotechnology, 17(5), 511-517.

Isacson, O. (2002). Models of repair mechanisms for future treatment modalities of Parkinson's disease. Brain Research Bulletin, 57(6), 839-846.

Ishii, K., Nakamura, M., Dai, H., Finn, T. P., Okano, H., Toyama, Y., \& Bregman, B. S. (2006). Neutralization of ciliary neurotrophic factor reduces astrocyte production from transplanted neural stem cells and promotes regeneration of corticospinal tract fibers in spinal cord injury. Journal of Neuroscience Research, 84(8), 1669-1681.

Iwanami, A., Kaneko, S., Nakamura, M., Kanemura, Y., Mori, H., Kobayashi, S., Kobayashi, S. Yamasaki, M., Momoshima, S., Ishii, H., Ando, K., Tanioka, Y., Tamaoki, N., Nomura, T., Toyama, Y., \& Okano, H. (2005). Transplantation of human neural stem cells for spinal cord injury in primates. Journal of Neuroscience Research, 80(2), 182-190.

Jat, P. S., Noble, M. D., Ataliotis, P., Tanaka, Y., Yannoutsos, N., Larsen, L., \& Kioussis, D. (1991). Direct derivation of conditionally immortal cell lines from an $\mathrm{H}-2 \mathrm{~Kb}$-ts A58 transgenic mouse. Proceedings of the National Academy of Sciences USA, 88(12), 5096-5100.

Jeong, J. A., Gang, E. J., Hong, S. H., Hwang, S. H., Kim, S. W., Yang, I. H., Ahn, C., Han, H., \& Kim, H. (2004). Rapid neural differentiation of human cord blood-derived mesenchymal stem cells. Neuroreport, 15(11), 1731-1734

Joannides, A., Gaughwin, P., Schwiening, C., Majed, H., Sterling, J., Compston, P. A., \& Chandran, S. (2004). Efficient generation of neural precursors from adult human skin: astrocytes promote neurogenesis from skin-derived stem cells. The Lancet, 364(9429), 172-178.

Jori, F. P., Napolitano, M. A., Melone, M. A., Cipollaro, M., Cascino, A., Altucci, L., Peluso, G., Giordano, A., \& Galderisi, U. (2004). Molecular pathways involved in neural in vitro differentiation of marrow stromal stem cells. Journal of Cellular Biochemistry, 94(4), 645-655.

Kang, K. S., Kim, S. W., Oh, Y. H., Yu, J. W., Kim, K. Y., Park, H. K., Song, C. H., \& Han, H. (2005). A 37-year-old spinal cordinjured female patient, transplanted of multipotent stem cells from human UC blood, with improved sensory perception and mobility, both functionally and morphologically: a case study. Cytotherapy, 7(4), 368-373.

Katzman, R. (1989). Alzheimer's disease is a degenerative disorder. Neurobiology of Aging, 10(5), 581-582.

Kennedy, P., Rogers, B., Speer, S., \& Frankel, H. (1999). Spinal cord injuries and attempted suicide: a retrospective review. Spinal Cord, 37(12), 847-852.

Levesque, M. (2004). Adult stem cell research: testimony to US Senate Committee on Comerce, Science \& Transportation. Washington: US Senate Committee on Commerce, Science \& Transportation.

Li, H. J., Liu, H. Y., Zhao, Z. M., Lu, S. H., Yang, R. C., Zhu, H. F., Cai, Y. L., Zhang, Q. J., \& Han, Z. C. (2004). Transplantation of human umbilical cord stem cells improves neurological function recovery after spinal cord injury in rats]. Zhongguo $\mathrm{Yi} X u$ Ke Xue Yuan Xue Bao, 26(1), 38-42.
Lim, D. A., Flames, N., Collado, L., \& Herrera, D. G. (2002). Investigating the use of primary adult subventricular zone neural precursor cells for neuronal replacement therapies. Brain Research Bulletin, 57(6), 759-764.

Lindvall, O. (1995). Neural transplantation. Cell Transplantation, 4(4), 393-400.

Lindvall, O. (2002). Stem cells for cell therapy in Parkinson's disease. Pharmacological Research, 47(4), 279-287.

Lindvall, O., \& Hagell, P. (2002). Cell replacement therapy in human neurodegenerative disorders. Clinical Neuroscience Research, 2(1-2), 86-92.

Lindvall, O., Rehncrona, S., Brundin, P., Gustavii, B., Astedt, B., Widner, H., Lindholm, T., Bjorklund, A., Leenders, K., Rothwell, J. C., Frackowiak, R., Marsden, C. D., Johnels, B., Steq, G., Freedman, R., Hoffer, B. J., Seiger, A., Byqdeman, M., Stromberg, I., \& Olson, L. (1989). Human fetal dopamine neurons grafted into the striatum in two patients with severe Parkinson's disease. A detailed account of methodology and a 6-month follow-up. Archives of Neurology, 46(6), 615-631.

Lund, R. D., \& Hauschka, S. D. (1976). Transplanted neural tissue develops connections with host rat brain. Science, 193, 582-584.

McCabe, P. M., Sheridan, J. F., Weiss, J. M., Kaplan, J. P., Natelson, B. H., \& Pare, W. P. (2000). Animal models of disease. Physiology \& Behavior, 68(4), 501-507.

McDonald, J. W., Liu, X. Z., Qu, Y., Liu, S., Mickey, S. K., Turetsky, D., Gottlieb, D. I., \& Choi, D. (1999). Transplanted embryonic stem cells survive, differentiate and promote recovery in injured rat spinal cord. Nature Medicine, 5(12), 1410-1412.

McGuckin, C. P., Forraz, N., Allouard, Q., \& Pettengell, R. (2004). Umbilical cord blood stem cells can expand hematopoietic and neuroglial progenitors in vitro. Experimental Cellular Restoration, 295(2), 350-359.

Mendonça, M. L., Freitas, G. R., Silva, S. A., Manfrim, A., Falcão, C. H., Gonzales, C., André, C., Dohmann, H., Bojorevic, R., \& Otero, R. M. (2006). Safety of intra-arterial autologous bone marrow mononuclear cell transplantation for acute ischemic stroke. Arquivos Brasileiros de Cardiologia, 86(1), 52-55.

Menendez, P., Bueno, C., \& Wang, L. (2006). Human embryonic stem cells: a journey beyond cell replacement therapies. Cytotherapy, $8(6), 530-541$

Modo, M., Cash, D., Mellodew, K., Williams, S., Fraser, S., Meade, T., Price, J., \& Hodges, H. (2002). Tracking transplanted stem cell migration using bifunctional, contrast agent-enhanced, magnetic resonance imaging. Neuroimage, $17(2), 803$.

Modo, M., Hopkins, K., Virley, D., \& Hodges, H. (2003). Transplantation of neural stem cells modulates apolipoprotein E expression in a rat model of stroke. Experimental Neurology, 183(2), 320-329.

Modo, M., Rezaie, P., Heuschling, P., Patel, S., Male, D. K., \& Hodges, H. (2002). Transplantation of neural stem cells in a rat model of stroke: assessment of short-term graft survival and acute host immunological response. Brain Research, 958(1), 70-82.

Morens, D. M., Davis, J. W., Grandinetti, A., Ross, G. W., Popper, J. S., \& White, L. R. (1996). Epidemiologic observations on Parkinson's disease: Incidence and mortality in a prospective study of middle-aged men. Neurology, 46(4), 1044-1050.

Muir, J. L., Page, K. J., Sirinathsinghji, D. J., Robbins, T. W., \& Everitt, B. J. (1993). Excitotoxic lesions of basal forebrain cholinergic neurons: effects on learning, memory and attention. Behavioural Brain Research, 57(2), 123-131.

Nakafuku, M., \& Nakamura, S. (1995). Establishment and characterization of a multipotential neural cell line that can conditionally generate neurons, astrocytes, and oligodendrocytes in vitro. Journal of Neuroscience Research, 41(2), 153-168.

Nishio, Y., Koda, M., Kamada, T., Someya, Y., Yoshinaga, K., Okada, S., Harada, H., Okawa, A., Moriya, H., \& Yamazaki, M. (2006). The use of hematopoietic stem cells derived from human umbilical cord blood to promote restoration of spinal cord tissue and recovery of hind limb function in adult rats. Journal of Neurosurgery Spine, 5(5), 424-433.

Noble, M., Groves, A., Ataliotis, P., Morgan, J., Peckham, M., Partridge, T., \& Jat, P. S. (1993). Biological and Molecular Approaches to the Generation of Conditionally Immortal Neural Cells. Neuroprotocols, 3(3), 189-199.

Noble, M., Groves, A. K., Ataliotis, P., Ikram, Z., \& Jat, P. S. (1995). The $\mathrm{H}-2 \mathrm{KbtsA} 58$ transgenic mouse: a new tool for the rapid generation of novel cell lines. Transgenic Research, 4(4), 215-225.

Odorico, J. S., Kaufman, D. S., \& Thomson, J. A. (2001). Multilineage differentiation from human embryonic stem cell lines. Stem Cells, 19(3), 193-204.

Ogawa, Y., Sawamoto, K., Miyata, T., Miyao, S., Watanabe, M. Nakamura, M., Bregman, B., Koike, M., Uchiyama, Y., Toyama, 
Y. \& Okano, H. (2002). Transplantation of in vitro-expanded fetal neural progenitor cells results in neurogenesis and functional recovery after spinal cord contusion injury in adult rats. Journal of Neuroscience Research, 69(6), 925-933.

Okano, H., Ogawa, Y., Nakamura, M., Kaneko, S., Iwanami, A., \& Toyama, Y. (2003). Transplantation of neural stem cells into the spinal cord after injury. Seminars in Cell \& Developmental Biology, 14(3), 191-198.

Olanow, C., Goetz, C., Kordower, J., Stoessl, A., Sossi, V., Brin, M., Shannon, K. M., Nauert, G. M., Perl, D. P., Godbold, J., \& Freeman, T. B. (2003). A double-blind controlled trial of bilateral fetal nigral transplantation in Parkinson's disease. Annals of Neurology, 54(3), 403-414.

Oliveira, A., Grygorian, G., \& Hodges, H. (2000a). Behavioural effects of MHP36 and MHP15 cell line grafts following AMPAinduced lesions of the nucleus basalis magnocellularis in rats. The International Journal of Neuropsychopharmacology, 3(Supplement 1), S360.

Oliveira, A., Grygorian, G., \& Hodges, H. (2000b). Recovery of spatial learning by grafts of a conditionally immortalised stem cell line after AMPA-induced lesions of the basal forebrain in rats. European Journal of Neuroscience, 12, 291.

Oliveira, A., \& Hodges, H. (2005). Alzheimer's Disease and Neural Transplantation as Prospective Cell Therapy. Current Alzheimer Research, 2(1), 79-95.

Oliveira, A., Majumdar, S., Ilia, M., Chadwick, A., Pilcher, H., Hodges, H., Price, J. (2002). Human neural stem cell line graft effects in rats after AMPA-induced lesions of the basal forebrain. Annals of the 3rd Federation of European Neuroscience Societies Meeting.

Oller, D. W., Meredith, J. W., Rutledge, R., Thomason, M., Clancy, T., Moylan, J., \& Foil, B. (1992). The relationship between face or skull fractures and cervical spine and spinal cord injuries: a review of 13,834 patients. Accident Analysis and Prevention, 24(2), 187-192.

Park, K. I., Liu, S., Flax, J. D., Nissim, S., Stieg, P. E., \& Snyder, E. Y. (1999). Transplantation of neural progenitor and stem cells: developmental insights may suggest new therapies for spinal cord and other CNS dysfunction. Journal of Neurotrauma, 16(8), 675-687.

Pau, K. Y., \& Wolf, D. P. (2004). Derivation and characterization of monkey embryonic stem cells. Reproductive and Biological Endocrinology, 2(1), 41.

Perry, E., Tomlinson, B. E., Blessed, G., Bergman, K., Gibson, P. H., \& Perry, R. H. (1978). Correlation of cholinergic abnormalities with senile plaques and mental test scores in senile dementia. British Medical Journal, 2, 1457-1459.

Ray, J., Palmer, T. D., Suhonen, J., Takahashi, J., \& Gage, F. H. (1997). Neurogenesis in the adult brain: lessons learned from the studies of progenitor cells from the embryonic and adult central nervous system. In F. H. Gage \& Y. Christen (Eds.), Isolation, Characterization and Utilization of CNS Stem Cells (Fondation Ipsen - Pour la Recherche Therapeutique ed., pp. 128-). New York: Springer-Verlag Berlin Heidelberg.

Redies, C., Lendahl, U., \& McKay, R. D. (1991). Differentiation and heterogeneity in T-antigen immortalized precursor cell lines from mouse cerebellum. Journal of Neuroscience Research, 30(4), 601-615.

Reubinoff, B. E., Itsykson, P., Turetsky, T., Pera, M. F., Reinhartz, E., Itzik, A., \& Ben-Hur, T. (2001). Neural progenitors from human embryonic stem cells. Nature Biotechnology, 19(12), 1134-1140.

Rezvani, M., Birds, D. A., Hodges, H., Hopewell, J. W., Milledew, K., \& Wilkinson, J. H. (2001). Modification of radiation myelopathy by the transplantation of neural stem cells in the rat. Radiation Research, 156(4), 408-412.

Rogers, I., \& Casper, R. F. (2004). Umbilical cord blood stem cells. Best Practice \& Research Clinical Obstetrics \& Gynaecology, 18(6), 893-908.

Roisen, F. J., Klueber, K. M., Lu, C. L., Hatcher, L. M., Dozier, A., Shields, C. B., \& Maguire, S. (2001). Adult human olfactory stem cells. Brain Research, 890(1), 11-22.

Sanchez-Ramos, J. R., Song, S., Kamath, S. G., Zigova, T., Willing, A., Cardozo-Pelaez, F., Stedeford, T., Chopp, M., \& Sanberg, P. (2001). Expression of Neural Markers in Human Umbilical Cord Blood. Experimental Neurology, 171(1), 109-115.

Scher, A. T. (1998). Rugby injuries to the cervical spine and spinal cord: a 10-year review. Clinical Sports Medicine, 17(1), 195-206.

Schuldiner, M., Yanuka, O., Itskovitz-Eldor, J., Melton, D. A., \& Benvenisty, N. (2000). From the Cover: Effects of eight growth factors on the differentiation of cells derived from human embryonic stem cells. Proceedings of the National Academy of Sciences of the USA, 97(21), 11307-11312.

Sinden, J. D., Rashid-Doubell, F., Kershaw, T. R., Nelson, A., Chadwick, A., Jat, P. S., Noble, M.D., Hodges, H., \& Gray, J. A. (1997). Recovery of spatial learning by grafts of a conditionally immortalized hippocampal neuroepithelial cell line into the ischaemia-lesioned hippocampus. Neuroscience, 81, 599-608.

Song, H.-j., Stevens, C. F., \& Gage, F. H. (2002). Neural stem cells from adult hippocampus develop essential properties of functional CNS neurons. Nature Neuroscience, 5(5), 438-445.

Stein, H., Rozen, N., Kaufman, H., \& Lerner, A. (2006). Adult (somatic) stem cells and the musculoskeletal system. Orthopedics, 29(5), 418-421.

Stein, M. I., Zhu, J., \& Emerson, S. G. (2004). Molecular pathways regulating the self-renewal of hematopoietic stem cells. Experimental Hematology, 32(12), 1129-1136.

Stenevi, U., Bjorklund, A., \& Svendgaard, N. A. (1976). Transplantation of central and peripheral monoamine neurons to the adult rat brain: techniques and conditions for survival. Brain Research, 114(1), 1-20.

Sugaya, K. (2005). Possible use of autologous stem cell therapies for Alzheimer's disease. Current Alzheimer Research, 2(3), 367-376.

Sugaya, K., \& Brannen, C. L. (2001). Stem cell strategies for neuroreplacement therapy in Alzheimer's disease. Medical Hypotheses, 57(6), 697-700.

Tarnowski, M., \& Sieron, A. L. (2006). Adult stem cells and their ability to differentiate. Medical Science Monitor, 12(8), RA154-163.

Thomson, J. A., \& Odorico, J. S. (2000). Human embryonic stem cell and embryonic germ cell lines. Trends in Biotechnology, 18(2), 53-57.

Tondreau, T., Lagneaux, L., Dejeneffe, M., Massy, M., Mortier, C., Delforge, A., \& Bron, D. (2004). Bone marrow-derived mesenchymal stem cells already express specific neural proteins before any differentiation. Differentiation, 72(7), 319-326.

Turgut, M., Akpinar, G., Akalan, N., \& Ozcan, O. E. (1996). Spinal injuries in the pediatric age group: a review of 82 cases of spinal cord and vertebral column injuries. European Spine Journal, $5(3), 148-152$.

Urdzikova, L., Jendelova, P., Glogarova, K., Burian, M., Hajek, M., \& Sykova, E. (2006). Transplantation of bone marrow stem cells as well as mobilization by granulocyte-colony stimulating factor promotes recovery after spinal cord injury in rats. Journal of Neurotrauma, 23(9), 1379-1391.

Veizovic, T., Beech, J. S., Stroemer, R. P., Watson, W. P., \& Hodges, H. (2001). Resolution of stroke deficits following contralateral grafts of conditionally immortal neuroepithelial stem cells. Stroke, 32(4), 1012-1019.

Vescovi, A. L., Parati, E. A., Gritti, A., Poulin, P., Ferrario, M., Wanke, E., Frolichsthal-Schoeller, P., Cova, L., Arcellana-Panlilio, M., Colombo, A., \& Galli, R. (1999). Isolation and cloning of multipotential stem cells from the embryonic human CNS and establishment of transplantable human neural stem cell lines by epigenetic stimulation. Experimental Neurology, 156(1), 71-83.

Vescovi, A. L., \& Snyder, E. Y. (1999). Establishment and properties of neural stem cell clones: plasticity in vitro and in vivo. Brain Pathology (Zurich, Switzerland), 9(3), 569-598.

Vickers, J. C., Dickson, T. C., Adlard, P.A., Saunders, H. L., King, C.E., \& McCormack, G. (2000). The cause of neuronal degeneration in Alzheimer's disease. Progress in Neurobiology, 60(2), 139-165.

Vogel, L. C., \& Anderson, C. J. (2003). Spinal cord injuries in children and adolescents: a review. Journal of Spinal Cord Medicine, 26(3), 193-203.

Wang, J. F., Wang, L. J., Wu, Y. F., Xiang, Y., Xie, C. G., Jia, B. B., Harrington, J., \& McNiece, I. K. (2004). Mesenchymal stem/ progenitor cells in human umbilical cord blood as support for ex vivo expansion of CD34 (+) hematopoietic stem cells and for chondrogenic differentiation. Haematologica, 89(7), 837-844.

Wang, Q., Matsumoto, Y., Shindo, T., Miyake, K., Shindo, A., Kawanishi, M., Kawai, N., Tamiya, T., \& Nagao, S. (2006). Neural stem cells transplantation in cortex in a mouse model of Alzheimer's disease. Journal of Medical Investigation, 53(1-2), 61-69.

Wheatley, K., Stowe, R. L., Clarke, C. E., Hills, R. K., Williams, A. C., \& Gray, R. (2002). Evaluating drug treatments for Parkinson's disease: how good are the trials? British Medical Journal, 324(7352), 1508-1511.

Whitehouse, P. J., Price, D. L., Struble, R. G., Clark, A. W., Coyle, J. T., \& DeLong, M. R. (1982). Alzheimer's disease and senile dementia: loss of neurons in the basal forebrain. Science, 215, 1237-1239.

Whitehouse, P. J., Struble, R. G., Hedreen, J. C., Clark, A. W., White, C. L., Parhad, I. M., \& Price, D.L. (1983). Neuroanatomical evidence for a cholinergic deficit in Alzheimer's disease. Psychopharmacology Bulletin, 19(3), 437-440.

Zeng, X., \& Rao, M. S. (2006). Human embryonic stem cells: long term stability, absence of senescence and a potential cell source for neural replacement. Neuroscience, 145(4), 1348-1358. 